\title{
How to Improve Journal of Local Universities and Colleges' Periodical Influence
}

\author{
Chunwei Shi ${ }^{\text {a }}$, Wenfeng Zhou ${ }^{\mathrm{b}}$, Ping Chen ${ }^{\mathrm{c}}$, Jinyu Song ${ }^{\mathrm{d}}$, Yaxin Wang ${ }^{\mathrm{e}}$ \\ Liaoning Shihua University, Liaoning 113001, China \\ ac08271827@126.com, bwenfeng@163.com, ccdywe@126.com, dwangd123@163.com, \\ ewyx123@126.com
}

Keywords: Journal of local university; external manuscripts; academic influence; diffusion factor; new media manuscripts.

\begin{abstract}
Journal of diffusion through the analysis of a small local colleges factors reasons put forward to improve the school's academic influence, build Sinica cards, multi-channel manuscripts and asked him to actively enhance, improve service levels Journal of ways to solve the draft Local University external source less diffusion factor is the problem of low Journal in place to achieve the purpose of academic quality and influence, such as better and faster development.
\end{abstract}

\section{Introduction}

Journal of colleges and universities is mainly for the school staff and students. The school published more, some journals of colleges and universities due to your journal source level high, the school scientific research level is high and the inner quality of draft high reason, for extramural manuscripts are shut sb. or set a higher threshold, the development of the autistic publication idea hindering of journals of colleges and universities, in order to coordinate internal and external contributions published ratio problem editor, many teachers have done a meaningful exploration ${ }^{[1-3]}$.

In the important index to evaluate the quality of the journal, diffusion factor (by the manuscript origin provinces number and author distribution of the number of institutions decided) involving the manuscript source distribution with respect to the number of the journals of local universities are not professional scientific journal ${ }^{[4]}$.Journals of local colleges and universities can be increased through external release quantity and improve the diffusion factor, to improve periodical influence, thus entered the high level print source. In this paper, except the release quantity and diffusion factor as example, explores the existing problems of the journals of local universities, and put forward some solutions, the editors of criticism, suggestions for improving the local university journal influence and actively offer.

\section{The reason of a small number and diffusion factor low external release}

\subsection{The school's academic influence}

The influential force of the journal is closely related with the academic influence of the school, if school influence is small, so the journal also not too easy to receive the extensive concern. The academic influence of school is the main guarantee of local university journal manuscript source. Journal of local universities because of school influence is low, so the external release quantity is less, the diffusion factor is low, the academic influence of slow increase.

\subsection{Characteristics of journals column settings}

Journals of local colleges and universities should be based on characteristics of subjects of this school, the characteristics and the combination of scientific research, Journal of characteristic columns are signs and card, can serve to enhance the role of Journal influence. However, the general journal is not according to the column select the manuscript, but based on the manuscript organization column, column features no series and persistence, cannot reflect the development of the characteristic discipline, useless. To establish the characteristic columns is the basic organization of 
the school of manuscript, school level with the disciplines of the manuscript is very few, has not formed the scale.

\subsection{The intensity and measures of manuscripts}

Journal of local university as the manuscript source internal relatively rich, so take the initiative out author's enthusiasm is not high, the basic or "wait" manuscript home situation. Because the local university journal is not dominant in the evaluation system of academic journals in China, so the high level expert few papers published in the Journal of local universities on. To write a single comparison, mainly is the email, phone calls, journal published artists enlightenment many journals are method, did not make full use of new media, such as micro-blog WeChat network publicity and packaging. The manuscripts range fixed, always some people who often contact received approximations letter, external release no new growth point, the contribution of the external situation could not open.

\section{The solution of the diffusion pathway factor low}

\subsection{To improve the academic influence of the school}

Journals of local colleges and universities should be some positive impact events and school character stories in print issue with journals, such as the school's subject construction has achieved what new progress, new increased which master's and doctoral degrees, which introduced a new talent, new purchase what advanced instruments etc. At the same time, the use of foreign activities, the school actively propaganda, raise the academic influence, the school's academic influence and journals such as, the school anniversary, alumni back to visit, the delegation of the foreign units, can be published in Journal of information issued to come to participate in the activities of the staff, to improve their academic influence through school and journal.

\subsection{Creating journal's business card.}

Characteristic columns in Journal of business card, how to run the characteristic section features columns is lasting, frontier, in order to attract papers related to outside of the unit, "Journal of Liaoning Shihua University" in 2012 the creation of "oil and gas storage and transportation" column, the column of 2013 published 24 articles, of which the outer release units including the Nanjing University, Shenyang, Sichuan University of Aeronautics and Astronautics petrochemical Southwest Petroleum University, Fushun petrochemical, such as 12 foreign manuscripts, effectively improve the diffusion factor and journal influence.

\subsection{To enhance the strength of multiple channels of manuscripts.}

For the unit outside the authors of articles (especially expert author) or supported by national, Provincial Foundation giving papers, journal can be based on a certain remuneration or royalties is about, so to be able to make up for the authors did not contribute to the high-grade journals reward loss, so as to improve the enthusiasm of the author's submission units. Journals of local colleges and universities should actively use modern means, try digital manuscripts, in addition to the cardboard manuscripts, also can send mail to related scientific research personnel, new media also use digital means the journal's website, blog, QQ, micro-blog. Improves the diffusion factor of journal. "Journal of Liaoning Shihua University" and alumni office cooperation, in 2010, 50 anniversary celebration, the Journal of the headmaster and the school anniversary celebration monographs and other information with the release or mailed to use alumni, alumni in the petroleum and petrochemical forefront work actively to their advantage, manuscripts, so far in 2013, received a total of 8 manuscripts of Panjin petrochemical, Sinopec Sichuan, Xinjiang Petrochemical 7 units, effectively expanding the external manuscripts, also published a batch factory actual production problems ${ }^{[5]}$.

Consolidation will issue the bibliography cited induction, find out nearly three years of units according to their author, subject characteristics, targeted to send them approximations letter, so as to achieve the purpose of attracting foreign high. This print 2008 published an article about the overseas operation of petroleum industry papers, of which, the author quoted Liu students of University of Science and Technology Liaoning published a paper in the "international oil economy" the editorial department, to Liu approximations letter, will be published journals have petroleum economic papers 
mailed to Mr. Liu, after 3 years of editorial department efforts, finally moved Liu, the other a student vote for this print manuscript.

\subsection{Improve the service level.}

For foreign manuscripts, editors should have special treatment, the expert review is not too busy can find the campus, cycle should also be limited in half a month. In order to let outside contributions can rapid publication, editorial department can be opened for foreign release "Easy Access", shortened the publication lag, and makes the author willing to continue submitting draft. In 2013 for each paper each field author mail Book Editorial Department of Journal of Liaoning Shihua University, this not only improves the circulation and expand the publication impact, and increased the number of authors submitting passion again ${ }^{[6]}$.

To cast off the manuscript authors regardless of whether the article was accepted, "Journal of Liaoning Shihua University" will be mailed to each of the Journal of the author, to the author to better understand this print dynamic, thus once again contribute. For example, this print 2007 received Qufu Normal University students of Liu's contribution, but not through the external audit, rejection, but the Editorial Department adhere to the teacher Liu mail the book, so the author in 08 years 09 years many contributors, published 2 papers ${ }^{[7]}$.

\section{Summary}

The high proportion in the draft, closed too strict, is bound to affect and the development of the limit of the local university journals. With the evaluation system of index change, Journal of local universities and colleges should also be timely adjusted, increasing the external release source, improving the manuscript origin provinces number and author distribution of the number of institutions. Construction of local university journals in the province and even the country within the scope of the famous degree, make the local Journal of better and faster development in the academic quality and influence and so on.

\section{References}

[1] Zhao Kunyan. Journal of colleges and universities outside contributions rising series of problems [J].Journal of Yunnan Normal University: Philosophy and Social Science Edition, 2006, 16 (4):137-141.

[2] Jiang Yaru, Zhao Daliang, Chen Haoyuan. Statistical Natural Science Journals of colleges and universities introspective analysis [J].Journal editors, 2012, 24 (4):396-398.

[3] Shi Qinghua, Peng Jiqian. Characteristics of the industry to serve the local economic development of University Journals -- a case study of Journal of Liaoning Technical University (Social Science Edition) based on the case study of the [J]. Journal of Liaoning Technical University: Social Science Edition, 2012 (3): 111-114.

[4] Liu Juan, Liu Cheng. Academic Journal of famous manuscripts strategy [J]. Journal of Xinjiang Normal University: Natural Science Edition, 2013, 32 (1): 88-90.

[5] Yan Peng. Analysis and comparison of [J]. Journal of Liaoning Shihua University of three kinds of plant gum fracturing fluid properties, 2013,33 (4): 13-15.

[6] Shaohua Yin, Shiwei Li, Wenyuan Wu, et al. Extraction and separation of Ce(III) and Pr(III)in the system containing two complexing agents with di-(2-ethylhexyl) phosphoric acid[J]. RSC Adv., 2014, 4 (104), 59997 - 60001.

[7] Bao Weimin from the school paper ratio analysis of changes in Journal of open manuscript source problem[J]. China journals of science and technology research, 2009, 20(1):166-168. 